\title{
Ponticulus posticus on the Posterior Arch of Atlas, Prevalence Analysis in Asymptomatic Patients
}

\author{
Ponticulus posticus en el Arco Posterior del Atlas, \\ Análisis de su Prevalencia en Pacientes Asintomáticos
}

"Juan Schilling; *Alejandro Schilling \& **Iván Suazo Galdames

SCHILling, J.; SCHILling, A. \& SUAZO, G. I. Ponticulus posticus on the posterior arch of atlas, prevalence analysis in asymptomatic patients. Int. J. Morphol., 28(1):317-322, 2010.

SUMMARY: The Ponticulus posticus is a bony bridge located in the posterior arch of the atlas in relation to the passage of the vertebral artery. Its presence has been associated with development of cervical pain and cerebrovascular disorders. The purpose of this study was to assess its prevalence in asymptomatic patients. We examined 436 digital teleradiographs of patients aged from 5 to 70 years (mean of 18.44 years, SD. 9.59) of both sexes (173 men, 263 women). In $80.7 \%(\mathrm{n}=352)$ of cases, no radiographic evidence of ossification was found; $19.3 \%$ showed some degree of ossification, of which $10.1 \%$ had partial ossification and $9.2 \%$ complete ossification. The prevalence of complete ossification was slightly higher in women than in men and occurs in all the age groups analyzed. Our results suggest that the Ponticulus posticus is an anatomic condition with a protective function.

KEY WORDS: Ponticulus posticus; Atlas; Verebral artery; Cervical pain.

\section{INTRODUCTION}

The ponticulus posticus is a bony arch that connects the retroglenoid tubercle located posterior to the superior articular fossa of the atlas with their posterior arch (Miki et al., 1979). This element has been described in classical literature as an anatomical variation that originates in the ossification of the lateral segment of the posterior atlantooccipital ligament or the capsule of this joint (Testut \& Latarjet, 1999; Paturet, 1951). Its importance lies in the relationship established with the vertebral artery, which, after leaving the foramen transversarium of the atlas vertebra, relies on its posterior arch and through the usually fibroosseous foramen in search of the posterior atlantooccipital membrane, which it pierces to enter into the vertebral canal.

This bony bridge has been called by different names, such as sagittale foramen and atlantal posterior foramen by Loth-Niemirycz (1916); arcuate foramen, a variant of Kimmerle's anomaly (Kimmerle, 1930); upper retroarticular foramen (Brocher, 1955); canalis vertebralis (WolffHeidegger, 1961); retroarticular vertebral artery ring
(Lamberty \& Zivanovic, 1973); arcuate foramen (Stubbs, 1992); retroarticular canal (Mitchell, 1998a); and retrocondilar vertebral artery ring (Mitchell, 1998b). However, its most accepted name is ponticulus posticus (Latin for little posterior bridge) (Cho, 2009; Young et al., 2005).

According Miki et al., radiographically, the Ponticulus posticus can be classified into three types:

Full type: it forms a complete bony ring.

Incomplete type: some portions of the bony ring are defective. Calcified type: there is a linear or amorphous calcification.

In lateral cervical spine radiography, we can observe a bony ring (Fig. 1). The presentation of these bony arches or bony bridges can be unilateral or bilateral (Cho). While the observation of this calcification is not a diagnosis issue, determining their location (unilateral or bilateral) and identifying the affected side of $\mathrm{C} 1$ is very difficult with lateral and anteroposterior radiographic views.

\footnotetext{
* Departamento de Estomatología. Facultad de Ciencias de la Salud. Universidad de Talca, Chile.

***pepartamento Ciencias Básicas Biomédicas. Facultad de Ciencias de la Salud, Universidad de Talca, Chile.
} 


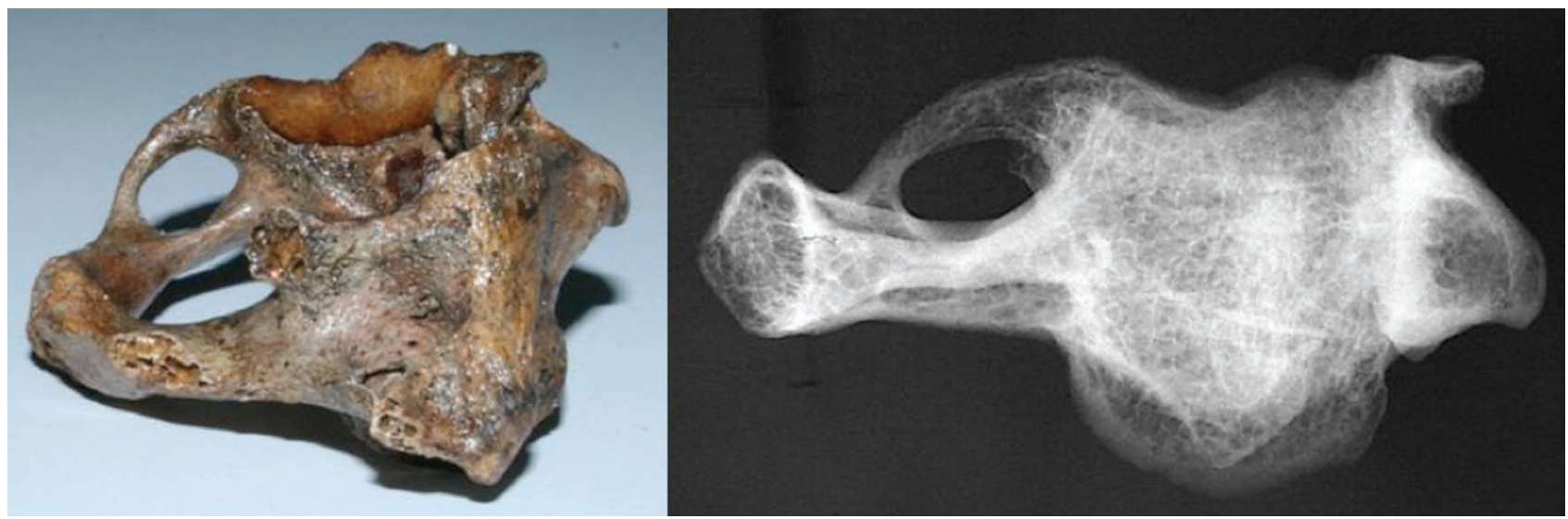

Fig. 1. Ponticulus posticus, bony arch that connects the superior articular condyle and the posterior arch of the atlas, we can observe the presence of one Ponticulus posticus in dry atlas and in radiographic of anatomical piece on lateral views.

There are numerous clinical considerations about this bony arch. The presence of the Ponticulus posticus has been linked to migraine development (Wight et al., 1999). It must also be taken into account during the immobilization of the cervical spine with lateral mass fixation in $\mathrm{C} 1$, given the relationship of the bony arch or ring with the vertebral artery (Young et al.). In addition, the presence of the calcification has been related with shoulder and arm pain, neck pain, headaches, and dizziness (Cakmak et al., 2005).

The prevalence of this anatomical variation is relatively high. In a study on 60 atlas vertebra in European individuals, 22 cases (36.6\%) had this ossification; in 15\% the ring was complete, and $21.6 \%$ had partial ring ossification (Lamberty \& Zivanovíc).

Young et al. found a prevalence of $15.5 \%$ in lateral neck radiographs. On dry vertebrae, Simsek et al. (2008) found a prevalence of 5.6\% with a partial bony arch (9 cases, 8 bilateral and 1 unilateral) and $3.8 \%$ with a complete bony arch in all samples. Cakmak et al., also in a study of dry atlas, found a prevalence of $11.7 \%$ of cases with a complete bony arch and $3.3 \%$ cases with partial formation of the arch.

In terms of prevalence by sex, the presentation of a complete bony arch is slightly higher in men (11.11\%) compared with women (9.3\%) (Paraskevas et al., 2005).
Paraskevas et al. believed the prevalence of the ponticulus posticus is related to age; however, there are no studies evaluating the presence of this formation in subadults.

Against this background, the purpose of this study is to determine the prevalence of the ponticulus posticus in a group of adults and subadults by observing teleradiographs.

\section{MATERIAL AND METHOD}

We designed a descriptive cross-sectional study.

Sample. Using non-probability convenience sampling, we selected 436 digital lateral cephalometric radiographs of patients with orthodontic indication from the files of a private radiology center in the Maule region. The radiographs were obtained with a Siemens Sirona ORTHOPOS XG 5® in standard position. The patients, of which $60.3 \%$ were female and $39.7 \%$ were male, had a mean age of 18.44 years (SD 9.597). The sample characteristics are presented in Table I.

We excluded radiographs that showed lateral inclination of the posterior arch of the atlas, and mastoid process overjet on the body and the posterior arch of the atlas. Patients with a history of trauma or surgery in the cervical spine were also excluded from the study.

Table I. Sex distribution by age group.

\begin{tabular}{|c|c|c|c|c|c|c|c|c|c|}
\hline & & & & & Age Gr & & & & Total \\
\hline & & $\begin{array}{l}<10 \\
\text { years }\end{array}$ & $\begin{array}{l}11 \text { to } 20 \\
\text { years }\end{array}$ & $\begin{array}{c}21 \text { to } 30 \\
\text { years }\end{array}$ & $\begin{array}{c}31 \text { to } 40 \\
\text { years }\end{array}$ & $\begin{array}{c}41 \text { to } 50 \\
\text { years }\end{array}$ & $\begin{array}{c}51 \text { to } 60 \\
\text { years }\end{array}$ & $\begin{array}{c}61 \text { to } 70 \\
\text { years }\end{array}$ & \\
\hline Sex & Female & 36 & 142 & 56 & 20 & 5 & 3 & 1 & 263 \\
\hline & Male & 28 & 108 & 14 & 17 & 5 & 1 & 0 & 173 \\
\hline Total & & 64 & 250 & 70 & 37 & 10 & 4 & 1 & 436 \\
\hline
\end{tabular}


Diagnostic Procedures. The observation was made by two maxillofacial radiologists who made the diagnosis by consensus, eliminating from the sample those images that are subject to discussion. The images were viewed on a flatscreen TFT - LCD monitor (Thin Film Transistor - Liquid Crystal Display) with a resolution of $2808 \times 2148$ pixels in JPEG (Joint Photographic Experts Group) format with 24bit grayscale.

Cases were classified into two categories (partial ossification and complete ossification) (Fig. 2), and the prevalence by sex and age group determined.

\section{RESULTS}

Some degree of ossification were seen in $19.3 \%$ of cases, of which $10.1 \%$ had partial ossification and $9.2 \%$ com- plete ossification (Fig. 3); the remaining 80.7\%, corresponding to 352 cases, did not show radiographic evidence of ossification (Table II).

The age distribution data on the study sample indicate that the average age of patients without the ponticulus posticus is 17.8 years (SD 9.1). The average age corresponds to 19.5 years (SD 9.732) in patients with a partial bony bridge and 22.88 years (SD 12.279) in cases with complete formation of the bony ring.

The data indicate that the distribution of the presence of the bony bridge in the first cervical vertebra is higher in females than in males. The female patients had partial ossification of the ponticulus ponticus in 29 cases $(6.7 \%$ of total sample) and complete ossification in 17 cases (3.9\%). In comparison, the male patients showed partial ossification in 15 cases $(3.44 \%)$ and complete ossification in 23 cases $(5.27 \%)$.

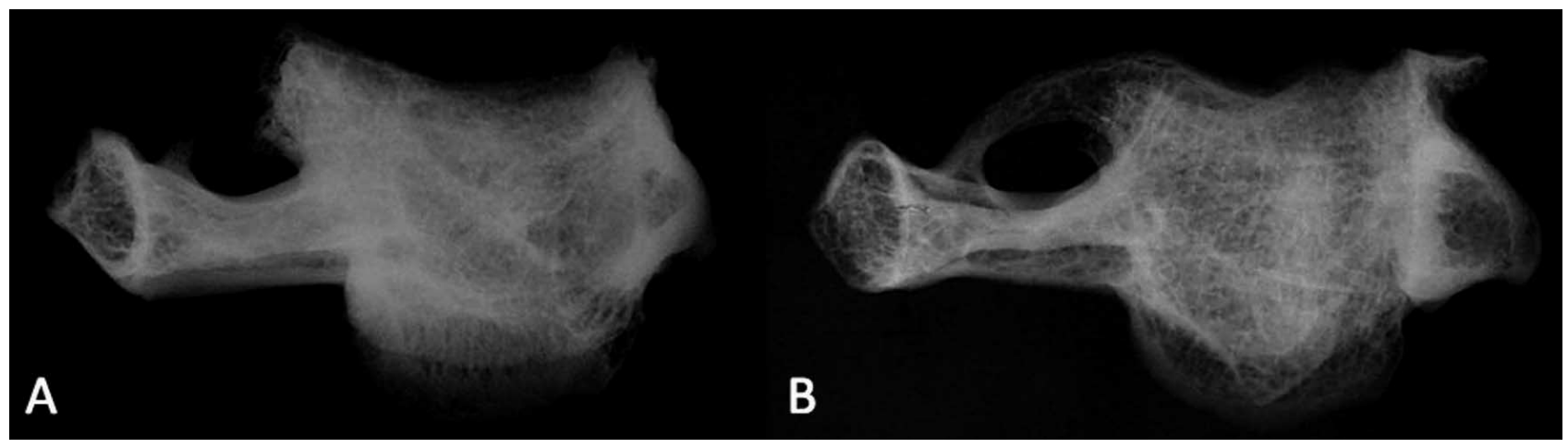

Fig. 2. Examples of ossification of the vertebral artery bony ring. (A) Partial ossification, (B) Complete ossification.

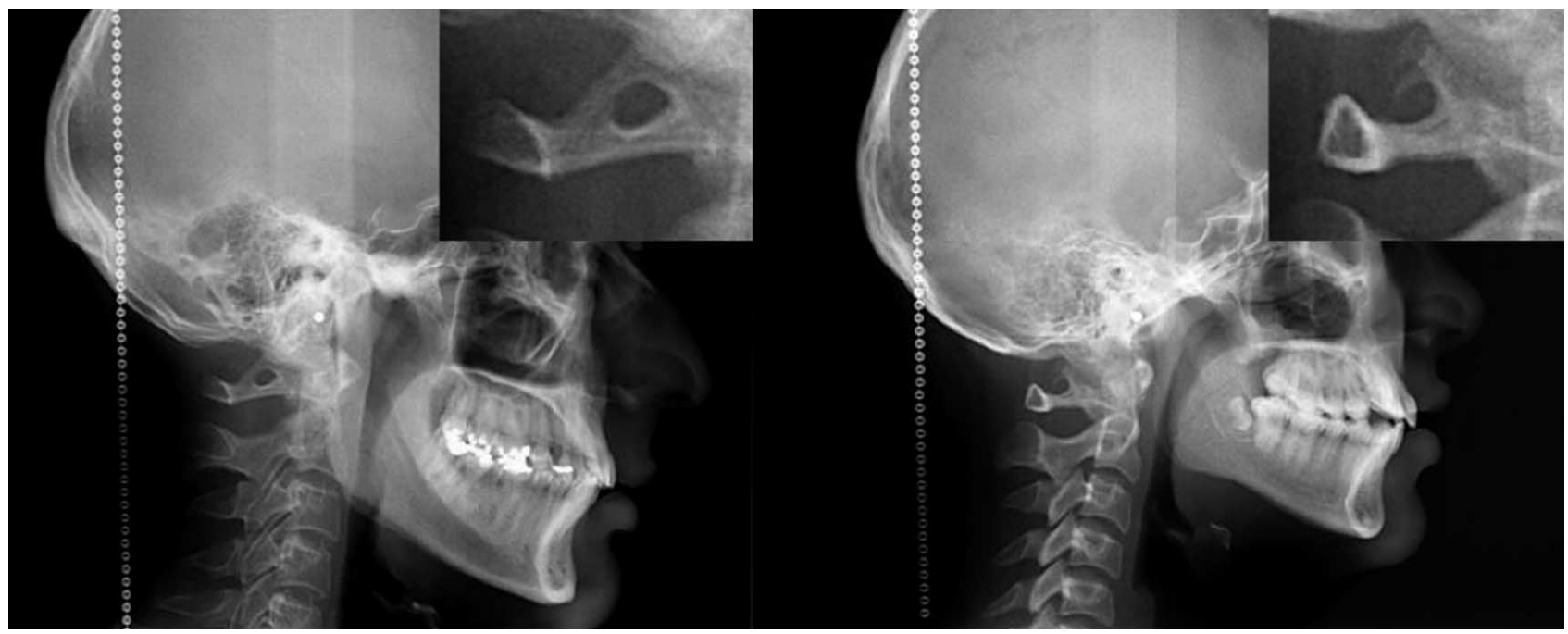

Fig. 3. In the left image observed a complete bony bridge while the right image shown a partial ossification. 
Table II. Prevalence of Ponticulus posticus.

\begin{tabular}{llcccc}
\hline & & Frequency & Percent & Valid & Cumulative Percent \\
\hline Valid & Absent & 352 & 80.7 & 80.7 & 80.7 \\
& Parcial & 44 & 10.1 & 10.1 & 90.8 \\
& Total & 40 & 9.2 & 9.2 & 100.0 \\
& Total & 436 & 100.0 & 100.0 & \\
\hline
\end{tabular}

Table III. Distribution by age group of Ponticulus posticus.

\begin{tabular}{|c|c|c|c|c|c|c|c|c|c|c|}
\hline & & & & & & Age Grou & & & & Total \\
\hline & & & $\begin{array}{l}0 \text { to } 10 \\
\text { years }\end{array}$ & $\begin{array}{c}11 \text { to } 20 \\
\text { years }\end{array}$ & $\begin{array}{c}21 \text { to } 30 \\
\text { years }\end{array}$ & $\begin{array}{c}31 \text { to } 40 \\
\text { years }\end{array}$ & $\begin{array}{c}41 \text { to } 50 \\
\text { years }\end{array}$ & $\begin{array}{c}51 \text { to } 60 \\
\text { years }\end{array}$ & $\begin{array}{c}61 \text { to } 70 \\
\text { years }\end{array}$ & \\
\hline \multirow[t]{6}{*}{ Ponticulus } & Absent & Count & 57 & 206 & 52 & 27 & 7 & 2 & 1 & 352 \\
\hline & & $\%$ & $13.1 \%$ & $47.2 \%$ & $11.9 \%$ & $6.2 \%$ & $1.6 \%$ & $.5 \%$ & $.2 \%$ & $80.7 \%$ \\
\hline & Parcial & Count & 4 & 24 & 11 & 3 & 2 & 0 & 0 & 44 \\
\hline & & $\%$ & $.9 \%$ & $5.5 \%$ & $2.5 \%$ & $.7 \%$ & $.5 \%$ & $.0 \%$ & $.0 \%$ & $10.1 \%$ \\
\hline & Total & Count & 3 & 20 & 7 & 7 & 1 & 2 & 0 & 40 \\
\hline & & $\%$ & $.7 \%$ & $4.6 \%$ & $1.6 \%$ & $1.6 \%$ & $.2 \%$ & $.5 \%$ & $.0 \%$ & $9.2 \%$ \\
\hline \multirow[t]{2}{*}{ Total } & & Count & 64 & 250 & 70 & 37 & 10 & 4 & 1 & 436 \\
\hline & & $\%$ & $14.7 \%$ & $57.3 \%$ & $16.1 \%$ & $8.5 \%$ & $2.3 \%$ & $.9 \%$ & $.2 \%$ & $100.0 \%$ \\
\hline
\end{tabular}

The distribution of the Ponticulus posticus prevalence (Table III) shows a greater concentration of cases in the age group of 11 to 20 years, with a prevalence of $5.5 \%$ for partial ossification of the bridge bone cases and $4.6 \%$ for total ossification, followed by the age group of 21 to 30 years, with a prevalence of $2.5 \%$ and $1.6 \%$ for partial and total ossification, respectively.

\section{DISCUSSION}

This study found a slightly higher prevalence as described in the literature (Young et al.; Simsek et al.; Cakmak et al.). While prevalence is similar, the striking difference in gender distribution, showing a higher prevalence in female patients $(10.6 \%)$ than men $(8.71 \%)$, which differs from that described by Paraskevas et al. This may be explained by the distribution by sex in the sample, of which $60.3 \%$ were women.

Multiple pathological processes related to the presence of the Ponticulus ponticus (Wight et al.; Cakmak et al.) have been reported. However, the observations in this study are consistent with radiographic findings and the presenting complaints of these patients were prescribed orthodontic and no cervical symptoms.
As indicated by Hasan et al. (2001), the origin of the bony bridge is an issue. Previous studies have suggested it may be a product of congenital development (Allen, 1879; Cleland, 1960; Von Törklus et al., 1975), a genetic trait (Selby et al., 1955), an ossification due to age (Pyo \& Lowman, 1959; Epstein, 1955; Breathnach, 1965; White \& Panjabi, 1978), or the result of external mechanical factors (Taitz \& Nathan, 1986).

Although the possibility that the calcification of the bony bridge progresses over time from an incomplete bony arch to complete ossification has been described by Paraskevas et al., this study found no clear relationship with age, since we found 3 cases of children under 10 years with complete ossification and 4 cases with partial ossification. Thus, while ossification is most likely a gradual process, its initiation is not likely to be related to the age of the patient. This would confirm the findings of Lamberty \& Zivanovic, who observed the ponticulus posticus cartilage in fetuses and children.

Taitz \& Nathan studied 672 atlas vertebra, of which $25.9 \%$ had a partial posterior bridge and $7.9 \%$ a complete bony bridge. They found that partial bony bridges predominate in younger age groups (10 to 30 years) and complete bony bridges in the older age groups (30 to 80 years), which differs from our findings that both partial and 
complete bone bridges had a higher prevalence among the age groups of 11 to 20 years and 21 to 30 years (Table III).

Our results suggest that the presence of the Ponticulus posticus is a condition independent of age, and therefore should not be considered a calcification or an ossification of the lateral segment of the posterior atlantooccipital ligament, but rather an ossification with functional significance, developed in other primates (Krishnamurthy et al., 2007) in order to protect the passage of the vertebral artery in a region which, by its sinuosity, is susceptible to being damaged or compressed as a result of craniocervical dynamics.

SCHILliNG, J.; SCHILliNG, A. \& SUAZO, G. I. Ponticulus posticus en el arco posterior del atlas, análisis de su prevalencia en pacientes asintomáticos. Int. J. Morphol., 28(1):317-322, 2010.

RESUMEN: El Ponticulus posticus es un puente óseo ubicado en el arco posterior de atlas en relación al paso de la arteria vertebral. Su presencia se ha asociado al desarrollo de cervicalgias y trastornos vasculares encefálicos. El propósito de este estudio fue analizar su prevalencia en pacientes asintomáticos, para ello fueron examinadas 436 teleradiografías digitales de pacientes de entre 5 y 70 años (Media 18,44 años; DS 9,59), de ambos sexos (173 hombres; 263 mujeres). En el 80,7\% (n=352) no se encontraron signos radiográficos de osificación, el 19,3\% de los casos se pudo apreciar algún grado de osificación, de los cuales el 10,1\% presento una osificación parcial y el 9,2\% completa. La prevalencia de osificación completa fue levemente mayor en mujeres y se presentó en todos los grupos etáreos analizados. Nuestros resultados sugieren que el Ponticulus posticus es una condición anatómica destinada a proteger el paso de la arteria verebral y no debe considerarse una calcificación con significado patológico.

PALABRAS CLAVE: Ponticulus posticus; Atlas; Arteria Vertebral; dolor cervical.

\section{REFERENCES}

Allen, W. On the varieties of the atlas in the human subject, and the homologies of its transverse processes. J. Anat., 14:18-28, 1879.

Breathnach, A. S. Frazer's Anatomy of the Human Skeleton. $6^{\text {th }}$ ed. London, J. \& A. Churchill, 1965. p. 29.

Brocher, J. E. W. Die Occipito-Cervical-Gegend. Stuttgart, Thieme, 1955.

Cakmak, O.; Gurdal, E.; Ekinci, G.; Yildiz, E. \& Cavdar, S. Arcuate foramen and its clinical significance. Saudi. Med. J., 26:1409-13, 2005.

Cho, Y. J. Radiological Analysis of Ponticulus Posticus in Koreans. Yonsei. Med. J., 50(1):45-9, 2009.

Cleland, M. On the serial homologies of the articular surfaces of the mammalian atlas, axis and occipital bone. Proc. R. Soc. Edinb., 2:221, 1860.

Epstein, B. S. The Spine: A Radiological Text and Atlas. Philadelphia, Lea and Febiger, 1955.

Hasan, M.; Shukla, S.; Siddiqui, M. S. \& Singh, D. Posterolateral tunnels and ponticuli in human atlas vertebrae. J. Anat., 199(3):339-43, 2001.

Kimmerle, A. Mitteilung über einen eigenartigen Befund am Atlas. Rontgenpraxis, 2:479-80, 1930.
Krishnamurthy, A.; Nayak, S. R.; Khan, S.; Prabhu, L. V.; Ramanathan, L. A.; Ganesh Kumar, C. \& Prasad Sinha, A. Arcuate foramen of atlas: incidence, phylogenetic and clinical significance. Rom. J. Morphol. Embryol., 48:263-6, 2007.

Lamberty, B. G. H. \& Zivanovíc, S. The Retro-articular vertebral artery ring of the atlas and its significance. Acta Anat., 85:113-22, 1973.

Loth-Niemerycz, J. Badania anatomiczne i antropologiczne nad kanalem wyrostkow poprzecznych (Canalis transversarius) kregow szyowych czlowieka i malp. Prace Towarzystwa Naukowego Warszawskiego, III:192, 1916.

Miki, T.; Oka, M.; Urushidani, H.; Hirofuji, E.; Tanaka, S. \& Iwamoto, S. Ponticulus Posticus: Its Clinical Significance. Acta Medica Kinki Univ., 4(2):427-30, 1979.

Mitchell, J. The incidence and dimensions of the retroarticular canal of the atlas vertebra. Acta Anat. (Basel), 163:113-20, 1998a.

Mitchell, J. The incidence of the lateral bridge of atlas vertebra. J. Anat., 193:283-5, 1998b.

Paraskevas, G.; Papaziogas, B.; Tsonidis, C. \& Kapetanos, G. Gross morphology of the bridges over the vertebral artery groove on the atlas. Surg. Radiol. Anat., 27(2):129-36, 2005. 
SCHILlinG, J.; SCHILLING, A. \& SUAZO, G. I. Ponticulus posticus on the posterior arch of atlas, prevalence analysis in asymptomatic patients. Int. J. Morphol., 28(1):317-322, 2010.

Paturet, G. Traité d'anatomie humaine. Paris, Masson, 1951.

Pyo, J. \& Lowman, R. M. The ponticulus posticus of the first cervical vertebra. Radiology, 72(6):850-4, 1959.

Simsek, S.; Yigitkanli, K.; Comert, A.; Acar, H. I.; Seckin, H.; Er, U.; Belen, D.; Tekdemir, I. \& Elhan, A. Posterior osseous bridging of C1. J. Clin. Neurosci., 15(6):686-8, 2008.

Selby, S.; Garn, S. M. \& Kanareff, V. The incidence and familial nature of a bony bridge on the first cervical vertebra. Am. J. Phys. Anthropol., 13(1):129-41, 1955.

Stubbs, D. M. The arcuate foramen. Variability in distribution related to race and sex. Spine (Phila. Pa., 1976), 17(12):1502-4, 1992.

Taitz, C. \& Nathan, H. Some observations of the posterior and lateral bridge of the atlas. Acta Anat. (Basel), 85:11322, 1986.

Testut, L. \& Latarjet, A. Compendio de Anatomía Descriptiva. Barcelona, Salvat, 1999.

Von Törklus, D.; Rklus, D. \& Gehle, W. Die Obere Halswribelsaüle. Stuttgart, Thieme, 1975. Vol. 2.

White, A. A. \& Panjabi, M. M. Clinical Biomechanics of the Spine. Philadelphia, Lippincott, 1978.

Wight, S.; Osborne, N. \& Breen, A. C. Incidence of ponticulus posterior of the atlas in migraine and cervicogenic headache. J. Manipulative Physiol. Ther., 22(1):15-20, 1999.

Wolff-Heideggerg, G. Atlas der sytematischen Anatomie des Menschen. Auflage, Karger, 1961. Vol. 1.

Young, J. P.; Young, P. H.; Ackermann, M. J.; Anderson, P. A. \& Riew, K. D. The ponticulus posticus: implications for screw insertion into the first cervical lateral mass. $J$. Bone Joint Surg. Am., 87:2495-8, 2005.

\section{Correspondence to: Juan Andrés Schilling Lara \\ Departamento de Estomatología \\ Escuela de Odontología \\ Facultad de Ciencias de la Salud \\ Avenida Lircay $\mathrm{s} / \mathrm{n}$ \\ Universidad de Talca \\ Talca \\ CHILE}

Phone: 56-71-200476

Email:jschilling@utalca.cl

Received: 09-11-2009

Accepted: 21-12-2009 